\title{
Review: Tinjauan mengenai Fisiologi Bursa Fabricius pada Ayam
}

\author{
Physiology of Bursa Fabricius in Chicken: A Review \\ Muhammad Rifqi Ismiraj \\ Program Studi Peternakan, Fakultas Peternakan, Universitas Padjadjaran PSDKU Pangandaran, Pangandaran, Jawa Barat, Indonesia
}

\begin{abstract}
Abstrak
Bursa Fabricius merupakan salah satu organ yang penting dalam imunitas ayam. Telah dilaporkan sebelumnya bahwa pembentukan antibody pada ayam berlangsung secara intensif oleh sel B limfosit pada bursa Fabricius. Artikel tinjauan ini mengulas mengenai peran bursa Fabricius dalam tubuh ayam, perkembangannya selama masa embriogenesis, dan perkembangannya setelah masa penetasan. Selain itu, dibahas pula mengenai karakteristik immunoglobulin pada ayam beserta dengan peranannya dalam membangun imunitas tubuh ayam. Artikel tinjauan ini juga mengulas perbandingan antara mekanisme pembentukan antibodi pada ayam dengan hewan pengerat, primata, dan mamalia. Artikel tinjauan ini bertujuan untuk merekam dan menyarikan berbagai laporan hasil penelitian dalam cakupan fisiologi organ bursa Fabricius pada ayam.
\end{abstract}

Kata Kunci: Bursa Fabricius, Sel B Limfosit, Antibodi, Ayam, Perkembangan.

\section{Abstract}

Bursa of Fabricius is one of the important organs in the immunity of chickens. It has been previously reported that the formation of antibodies in chickens takes place intensively by lymphocyte B cells on the bursa of Fabricius. This review article examines the role of the bursa of Fabricius in the body of chickens, its development during embryogenesis, and its development after hatching. In addition, it also discusses the characteristics of immunoglobulins in chickens and their role in building immunity in chickens. This review article also examines the comparison between the mechanism of antibody formation in chickens and rodents, primates and mammals. This review article aims to record and extract various research reports on the physiology of Fabricius bursa organs in chickens.

Keywords: Bursa of Fabricius, Lymphocyte B cells, Antibodies, Chicken, Development.

\section{PENDAHULUAN}

Artikel "Bursa of Fabricius and Antibody Production" oleh Bruce Glick, Timothy S. Chang, dan R. George Jaap pada tahun 1956 pertama kali menunjukkan peran bursa dalam perkembangan sistem kekebalan tubuh. Unggas, termasuk ayam, memiliki organ yang khas, yaitu bursa Fabricius. Organ ini telah dikenali selama lebih dari 300 tahun sebelum fungsinya dijelaskan pada tahun 1956. Penemuan bursa sebagai komponen penting dari respon imun dimulai secara tidak sengaja. Pengangkatan bursa (bursektomi) selama periode pertumbuhan mengurangi respon antibodi terhadap Salmonella. Sebuah makalah yang menjelaskan temuan luar biasa ini awalnya ditolak oleh jurnal Science dan akhirnya diterbitkan di jurnal Poultry Science. Penemuan ini memicu peristiwa berurutan yang mengarah pada pemahaman dikotomi tanggapan kekebalan. Pekerjaan tambahan di beberapa laboratorium selama bertahun-tahun mengungkapkan mekanisme kekebalan fundamental yang disebabkan bursa. Memahami mekanisme bursa Fabricius memajukan ilmu pertanian dan biomedis (Taylor dan McCorkle, 2009).
Penelitian yang dilakukan oleh Glick et al. (1956) tersebut berprinsip pada bursektomi, yaitu prosedur operasi pengangkatan bursa fabricius tersebut pada ayam yang baru menetas. Hasil penelitiannya menunjukkan bahwa pada ayam yang dilakukan bursektomi, tidak ditemukan pembentukan antibody ketika individu ayam tersebut disuntikkan antigen bakteri Salmonella typhimurium tipe O. Sejak saat itu, fungsi dari bursa fabricius menjadi lebih jelas, yaitu sebagai organ pusat pembentukan sel B dalam sistem imun unggas (Pike et al., 2004). Sedangkan di spesies lain, pembentukan sel B utamanya terjadi di sumsum tulang (bone marrow). Selanjutnya, penelitian baru-baru ini melaporkan bahwa pengangkatan bursa Fabricius (bursektomi) pada ayam secara nyata menurunkan tingkat immunoglobulin, khususnya $\mathrm{IgG} / \mathrm{IgY}$.

\section{BURSA FABRICIUS SEBAGAI GUT- ASSOCIATED LYMPHOID TISSUES (GALT)}

Bursa fabricius dikategorikan sebagai jaringan limfoid terkait usus/gut-associated lymphoid tissues (GALT), serupa dengan umbai cacing pada kelinci dan Peyer's Patch pada domba. Secara umum, GALT memiliki fungsi sebagai tempat produksi sel B matang yang 
terdiversifikasi (Pike et al., 2004). Sedangkan pada spesies lain, pembentukan sel B utamanya terjadi di sumsum tulang (bone marrow).

Perbandingan spesies yang berbeda secara evolusi ini akan memberikan wawasan tentang kejadian seluler spesifik yang diperlukan untuk diferensiasi prekursor menjadi sel B dewasa. Secara khusus, ayam memiliki keunikan dalam proses regulasi produksi sel B oleh kompleks reseptor sel B/B-cell receptor (BCR). Sumsum tulang tidak berperan dalam pembentukan sel $\mathrm{B}$ pada unggas, melainkan bursa Fabricius, sebuah organ GALT yang khusus, di mana terdapat limfopoiesis sel B (Pike et al., 2004). Namun ekspresi permukaan BCR telah dipertahankan sebagai titik pemeriksaan penting baik pada mamalia dan unggas di tengah variasi lingkungan mikro (Pike dan Ratcliffe, 2002). Dalam studi ini, kami akan membahas limfopoiesis sel B ayam, menggambarkan peran pengatur yang dipertahankan BCR, dan mendiskusikan data baru tentang bagaimana fungsi semacam itu diatur oleh BCR.

\section{GAMBARAN UMUM IMUNOGENESIS PADA AYAM}

Tidak seperti hewan pengerat (rodensia) dan primata, di mana repertoar antibodi primer dihasilkan secara eksklusif melalui proses penyusunan ulang genetik (genetic rearrangement), repertoar antibodi primer dalam ayam dihasilkan melalui proses konversi gen somatik (somatic gene conversion). Pada lokus rantai ringan (light chain) antibodi, terdapat gen daerah $\mathrm{V}$ fungsional $\left(\mathrm{V}_{\mathrm{L}}\right)$ unik yang mengalami penataan ulang menjadi segmen $\mathrm{J}\left(\mathrm{J}_{\mathrm{L}}\right)$ yang unik. Segmen $\mathrm{V}_{\mathrm{L}}$ dan $\mathrm{J}_{\mathrm{L}}$ yang sama digunakan di semua sel B, sementara ada beberapa keragaman junctional di persimpangan $\mathrm{VJ}_{\mathrm{L}}$, proses penataan ulang gen menghasilkan keragaman light chain minimal (Reynaud et al., 1987). Pola serupa juga muncul di lokus rantai berat (heavy chain) di mana terdapat segmen gen $\mathrm{V}_{\mathrm{H}}$ dan $\mathrm{J}_{\mathrm{H}}$ unik yang digunakan di semua sel B (Reynaud et al., 1989) dan di sekitar 15 elemen $\mathrm{D}_{\mathrm{H}}$ fungsional (Reynaud et al., 1991). Banyak dari elemen $\mathrm{D}_{\mathrm{H}}$ ini sangat mirip satu sama lain sehingga meskipun menggunakan elemen $D_{H}$ yang berbeda dan terdapat beberapa keragaman fungsi, gen $\mathrm{VDJ}_{\mathrm{H}}$ yang dihasilkan oleh penataan ulang menunjukkan jumlah keragaman yang sangat terbatas dibandingkan dengan tikus atau manusia. Baik pada lokus rantai ringan maupun lokus rantai berat immunoglobulin (Ig), terdapat famili hulu pseudogenes $\mathrm{JV}_{\mathrm{L}}$ dan $\mathrm{JV}_{\mathrm{H}}$, yang masingmasingnya tidak memiliki sekuens sinyal rekombinasi fungsional yang diperlukan bagi mereka untuk menjalani penataan ulang, tetapi tetap dapat menyumbangkan sekuens tersebut ke $\mathrm{VJ}_{\mathrm{L}}$ atau $\mathrm{VDJ}_{\mathrm{H}}$ yang diatur ulang secara fungsional gen (Reynaud et al., 1987, 1989). Proses ini dikenal sebagai konversi gen somatik dan merupakan mekanisme yang sangat kuat untuk menghasilkan repertoar antibodi. Baik organisasi genetik lokus Ig ayam dan jalur perkembangan sel $B$ pada ayam harus dipertimbangkan dalam terang generasi repertoar melalui konversi gen somatik dan jelas tergoda untuk menyimpulkan bahwa perbedaan dalam struktur lokus imunoglobulin, mekanisme untuk menghasilkan keragaman antibodi dan jalur perkembangan sel B telah berevolusi bersama.

\section{LIMFOPOIESIS SEL B PRA-BURSAL}

Pada mamalia dan ayam, sel hematopoietik dengan potensi untuk berdiferensiasi menjadi sel B pertama kali terdeteksi di splanknopleura para-aorta dan kemudian bermigrasi ke seluruh daerah yang melangsungkan hematopoiesis dalam embrio (Le Douarin et al., 1984; Dieterlen-Lievre, 1987; Godin et al., 1993; Gambar 1). Sel yang terikat pada garis keturunan sel B pertama kali terdeteksi di yolk sac pada hari ke 5 embriogenesis (hari ke 5) dengan adanya penataan ulang $\mathrm{DJ}_{\mathrm{H}}$ (Reynaud et al., 1992). Tidak seperti mamalia, penataan ulang gen imunoglobulin ayam tampaknya terbatas pada sel B, dan penataan ulang $\mathrm{DJ}_{\mathrm{H}}$ saat ini merupakan penanda definitif pertama dari komitmen terhadap garis keturunan sel B ayam (Reynaud et al., 1992). Meskipun demikian, adalah wajar untuk mengharapkan bahwa komitmen terbatas pada garis keturunan sel-B terjadi sebelum penataan ulang $\mathrm{DJ}_{\mathrm{H}}$ dan bahwa unggas yang setara dengan fraksi sel prapro-B yang diidentifikasi dalam sumsum tulang tikus (Li et al., 1996; Hardy et al., 2000) ada di dalam ayam.

\section{KARAKTERISTIK IMUNOGLOBULIN PADA AYAM}

Tiga jenis imunoglobulin ayam telah dijelaskan secara imunokimia (Leslie dan Clem, 1969; Leslie dan Martin, 1973) dan genetika (Dahan et al., 1983; Parvari et al., 1988; Mansikka, 1992) sebagai padanan untuk IgM, IgA dan IgG pada mamalia (Tabel 1) dan sifat strukturalnya telah dipelajari secara lebih mendalam pada artikel lain (Ratcliffe, 1996). IgM ayam secara struktural dan fungsional homolog dengan padanan mamalia, menjadi antibodi pertama yang diproduksi selama respon antibodi primer dalam serum sebagai pentamer dengan berat molekul tinggi dari unit m2L2. Kelas utama imunoglobulin yang diekspresikan pada sel limfosit $B$ ayam juga berupa IgM.

Dari sudut pandang filogenetik, IgG pada ayam memiliki karakteristik yang sama dengan $\operatorname{IgG}$ dan IgE pada mamalia dan sering disebut sebagai IgY pada unggas. IgG secara khusus dikembangkan secara fungsional dalam respons dan fungsi antibodi sekunder seperti homolog ayam dari IgG mamalia. Berpusat pada variasi sifat biokimia, seperti kondisi pengendapan garam, sebagai lawan dari fitur fungsional, klasifikasi IgY awalnya digunakan untuk Ig ayam dengan berat molekul rendah. Dengan mempertimbangkan homologi antara isoform Ig ini dan IgG mamalia, perbedaan yang paling mendasar secara struktural adalah terdapat perbedaan Panjang rantai saya akan menyarankan penggunaan klasifikasi IgG untuk isoform ayam. Namun, bebek mengirimkan dua varian isoform Ig dengan berat molekul rendah, tidak seperti ayam. Salah satu jenis 
adalah panjang maksimum, setara dengan IgG ayam, dan yang lainnya dipotong, kehilangan domain rantai kuat ketiga dan keempat (Magor et al., 1994). Karena jenis ini menunjukkan variasi fungsional dan struktural dari IgG panjang penuh, Pike et al. (2004) merekomendasikan penggunaan klasifikasi IgY untuk bentuk terpotong (Humphrey et al., 2004).

IgA ayam, juga identik dengan homolog mamalia, hadir dalam serum dan sekresi seperti empedu. Sejauh ini, tidak ada laporan mengenai kehadiran IgD mamalia pada homolog ayam. Sementara itu, IgM menjadi Ig permukaan semua sel pada sebagian besar sel B ayam. Demikian pula, tidak ada isotipe $\operatorname{IgE}$ yang teridentifikasi pada ayam, dengan IgG ayam diduga melakukan beberapa fungsi yang dianggap berasal dari IgE.

Hari ke-5 e

Splenknopleura Para-aorta

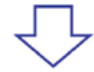

Hari ke 7-9e

Ginjal, yolk sac, sumsum tulang, dan sel darah

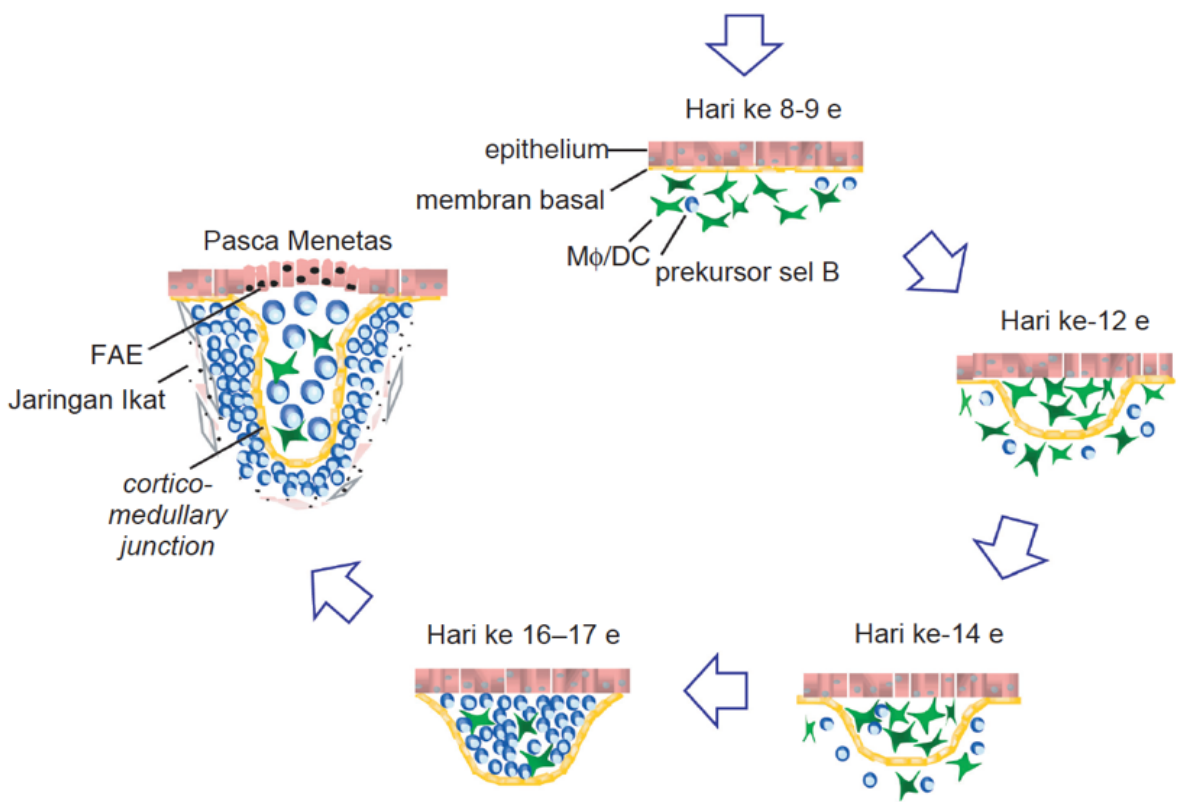

Gambar 1. Perkembangan sel B unggas. Bursa dikolonisasi oleh sel makrofag / dendritik (MФ/DC) serta prekursor sel B yang terikat. Perkembangan prekursor sel B menjadi tunas epitel tampaknya didahului oleh migrasi M $\Phi / D C$. Proliferasi sel B oligoklonal dalam folikel bursal embrio diikuti dengan redistribusi sel B ke daerah kortikal dan meduler setelah menetas. Redistribusi folikel terjadi saat jaringan epitel folikel (follicle-associated epithelium/FAE) berkembang. Akhiran e pada penulisan akhir keterangan hari di setiap tahap perkembangan merujuk pada "proses embriogenesis". Diadaptasi dari Pike et al. (2004).

Tabel 1. Karakteristik immunoglobulin ayam. Diadaptasi dari Ratclifte (2006).

\begin{tabular}{|c|c|c|c|}
\hline Karakter & $\lg M$ & $\lg G$ & $\lg A$ \\
\hline \multirow[t]{3}{*}{ Massa molekul } & $\sim 940 \mathrm{kDa}$ & $175 \mathrm{kDa}$ & 170 kDa pada serum \\
\hline & & & 350 kDa pada cairan empedu \\
\hline & & & 700 kDa pada sekresi lain \\
\hline \multirow[t]{2}{*}{ Konsentrasi normal dalam serum } & $1,3 \mathrm{mg} / \mathrm{ml}$ & $5,0 \mathrm{mg} / \mathrm{ml}$ & 0,3 mg/ml pada serum \\
\hline & & & 2-3 mg/ml pada cairan empedu \\
\hline \multirow[t]{3}{*}{ Struktur umum } & rantai $\mu_{10} L_{10}+J$ & $\gamma_{2} L_{2}$ & $\mathrm{a}_{2} \mathrm{~L}_{2}$ pada serum \\
\hline & & & rantai $a_{4} L_{4}+J$ pada serum \\
\hline & & & rantai $d_{8} L_{8}+J$ pada sekresi lain \\
\hline \multirow{2}{*}{$\begin{array}{c}\text { Struktur rantai berat (heavy chain/H } \\
\text { chain) }\end{array}$} & $70 \mathrm{kDa}$ & $67 \mathrm{kDa}$ & $65 \mathrm{kDa}$ \\
\hline & 5 domain $\left(\mathrm{V}_{\mathrm{H}}-\mathrm{C}_{\mu} 1-4\right)$ & 5 domain $\left(\mathrm{V}_{\mathrm{H}}-\mathrm{C}_{\gamma} 1-4\right)$ & 5 domain $\left(\mathrm{V}_{\mathrm{H}}-\mathrm{C}_{\mathrm{a}} 1-4\right)$ \\
\hline \multirow{3}{*}{$\begin{array}{c}\text { Homologi terhadap struktur rantai berat } \\
\text { (heavy chain/H chain) manusia } \\
\text { Struktur rantai ringan (light chain/L } \\
\text { chain) }\end{array}$} & $\begin{array}{l}\text { 33\% terhadap rantai } \mu \\
\text { manusia }\end{array}$ & $\begin{array}{c}\text { 31-32\% terhadap rantai } \\
\gamma \text { dan } \varepsilon \text { manusia }\end{array}$ & $35 \%$ terhadap rantai a manusia \\
\hline & $22 \mathrm{kDa}$ & & \\
\hline & 2 domain $\left(V_{L}-G_{L}\right)$ & & \\
\hline
\end{tabular}




\section{PERKEMBANGAN \\ REPERTOAR IMUNOLOGIS BURSA FABRICIUS PASCA LIMFOPOIESIS PRA-BURSAL}

Setelah kolonisasi folikel bursal oleh sel B yang mengekspresikan reseptor sIg prediversifikasi, program konversi gen diinduksi untuk mendiversifikasi gen $\mathrm{VDJ}_{\mathrm{H}}$ dan $\mathrm{VJ}_{\mathrm{L}}$ melalui konversi gen. Pada tahap inilah repertoar preimun dihasilkan. Beberapa bukti menunjukkan bahwa repertoar ini dihasilkan dengan cara yang tidak tergantung antigen. Yang paling meyakinkan, bukti ini berasal dari perkembangan repertoar di antara sel B yang didukung oleh reseptor sel T messenger (Tm; Grupp et al., 1993). Pada ayam yang mengekspresikan reseptor Tm, sekitar $20 \%$ dari Tm yang mengekspresikan sel B yang tidak memiliki ekspresi $\mathrm{sIg}$ endogen tetap mengandung pengaturan ulang $\mathrm{VDJ}_{\mathrm{H}}$ dan / atau $\mathrm{VJ}_{\mathrm{L}}$. Penataan ulang ini belum dipilih untuk produktivitas, konsisten dengan fakta bahwa ekspresi reseptor sIg endogen tidak berperan dalam memilih sel B ini ke dalam kolam bursal. Meskipun penataan ulang tidak produktif, mereka mengalami tingkat konversi gen yang tidak dapat dibedakan dari tingkat yang terlihat pada sel B normal pada saat yang sama (rata-rata peristiwa konversi gen independen per rantai cahaya pada saat menetas; Grupp et al., 1993). Selain itu, penggunaan pseudogen yang berbeda dalam sel B tersebut berkorelasi erat dengan penggunaan pseudogen dalam perkembangan sel B normal (Sanchez et al., 1993). Ini juga mendukung model di mana pengembangan repertoar primer didorong oleh ketersediaan sekuens pseudogen tanpa seleksi substansial untuk sekuens gen $\mathrm{V}$ tertentu. Jelas, jenis analisis ini tidak akan dapat mendeteksi perbedaan halus dalam repertoar yang mungkin terjadi sebagai konsekuensi dari seleksi negatif dari kekhususan reaktif diri. Oleh karena itu, pertanyaan muncul, apakah repertoar utama dipilih secara evolusioner untuk kekhususan yang 'berguna'. Secara teoritis, dapat dikatakan bahwa penggabungan situs yang berguna dapat dikodekan dalam cluster pseudogen. Namun, ada banyak heterogenitas dalam peristiwa konversi gen yang melibatkan pseudogen tertentu, dengan peristiwa konversi gen individu mulai dari beberapa kodon hingga fragmen besar pseudogen.

\section{PERKEMBANGAN PASCA MENETAS \\ STRUKTUR BURSA}

Selama perkembangan embrio, seluleritas bursa meningkat menjadi kira-kira $1 \times 10^{7}$ sel dan sel B bursal diatur dalam folikel yang tidak memiliki sub struktur yang jelas. Pada sekitar waktu menetas, struktur folikel bursal berubah dan folikel matang berkembang (Gambar 2). Selsel epitel bursal berkembang menjadi sel-sel khusus dari epitel folikel terkait (Ackerman dan Knouff, 1959). Selsel ini dikhususkan untuk bahan fagositosis dari lumen bursal dan mengangkutnya ke dalam kompartemen limfoid di bursa (Bockman dan Cooper, 1973; Schaffner et al., 1974; Sorvari et al., 1975). Dengan demikian, selsel ini tampaknya setara dengan sel M patch Peyer dan usus buntu di usus mamalia (Bockman dan Cooper, 1973). Perkembangan epitel terkait folikel di bursa terjadi tepat di atas setiap folikel sel B. Sel B dalam usus mamalia telah terbukti menginduksi pembentukan folikel terkait epitel (Golovkina et al., 1999) dan oleh karena itu masuk akal untuk mengharapkan bahwa kehadiran folikel sel B bursal mengarahkan perkembangan folikel terkait epitel. Sel-sel epitel yang berhubungan dengan folikel secara aktif mengangkut isi lumen bursal ke dalam kompartemen limfoid bursa. Karena lumen bursal dihubungkan ke lumen usus oleh saluran bursal, ini menyediakan mekanisme dimana perkembangan sel bursal B setelah menetas terjadi dengan adanya bahan yang berasal dari usus. Bahan-bahan ini termasuk antigen yang berasal dari usus tetapi sebagai tambahan dapat mengandung mitogen atau superantigen yang berasal dari bakteri.

Pada tahap perkembangan ini, beberapa sel bursal di kuncup epitel bermigrasi kembali melintasi membran basal untuk membentuk korteks luar sel yang mengelilingi medula pusat. Membran basal itu sendiri berkembang menjadi sambungan kortikomeduler kompleks yang berisi kapiler darah dan sinus limfatik. Karenanya, folikel yang

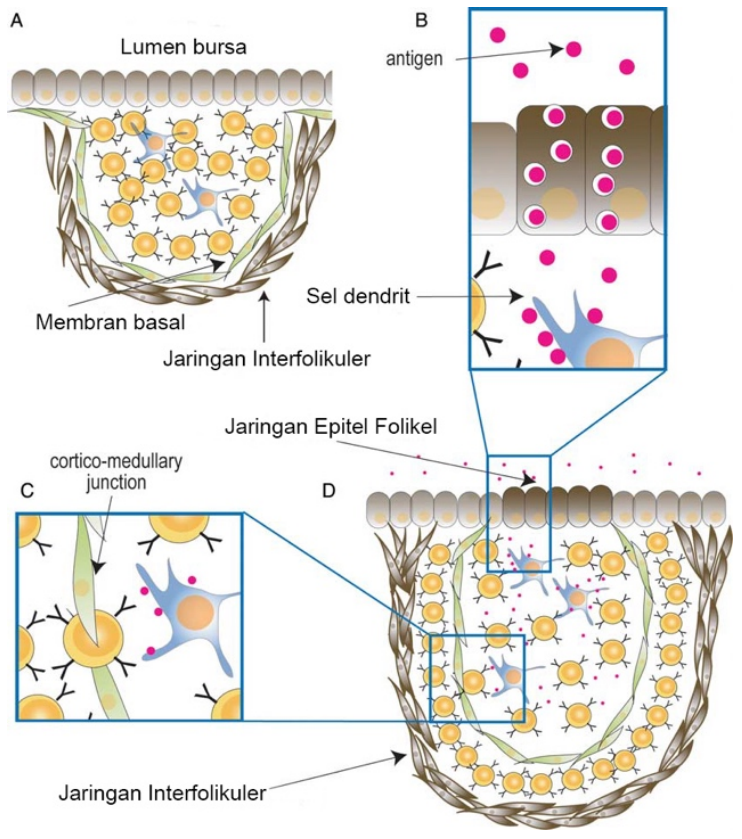

Gambar 2. Perkembangan bursa setelah menetas. (A) Pada saat menetas tunas epitel dipisahkan satu sama lain oleh jaringan ikat. (B) Tak lama setelah sel-sel menetas dari folikel epitel yang terkait berkembang dan secara aktif mengangkut isi lumen bursa (seperti antigen) ke dalam folikel bursal. (C) Beberapa limfosit bursal bermigrasi melintasi membran basal yang berkembang menjadi cortico-medullary junction yang kompleks. (D) Struktur folikel bursal yang matang pada periode pasca menetas. Diadaptasi dari Ratcliffe (2006).

matang mengandung medula sentral yang dikelilingi oleh daerah korteks dan di korteks inilah sebagian besar pembelahan sel terjadi setelah menetas. Beberapa bukti menunjukkan bahwa ada hubungan antara keberadaan molekul turunan usus dan perkembangan struktur kortikomeduler yang sesuai. Epitel bursal dari suatu tahap perkembangan sebelum mereka telah dijajah oleh prekursor sel B telah dicangkokkan ke dalam dinding perut dari embrio ayam yang sedang berkembang (Houssaint et al., 1983). Dalam keadaan ini, epitel ini 
dapat dikolonisasi oleh sel B inang dan mengembangkan struktur folikel yang normal. Namun setelah menetas, bursae ektopik ini tidak terus berkembang secara normal yang menunjukkan bahwa kontak dengan isi yang berasal dari usus mungkin diperlukan untuk perkembangan bursal yang normal setelah menetas. Demikian pula, dalam percobaan di mana duktus bursal diikat, perkembangan normal dari perkembangan sel B setelah menetas dikompromikan (Sayegh dan Ratcliffe, 2000).

Oleh karena itu, pertanyaan yang muncul adalah apakah peran molekul turunan usus dalam perkembangan sel bursal normal adalah untuk memberikan sinyal mitogenik yang tidak bergantung pada imunoglobulin permukaan atau untuk memberikan sinyal yang diperlukan untuk ligasi reseptor sel B. Termasuk di antara yang terakhir akan menjadi antigen spesifik yang dapat dikenali oleh repertoar sel B yang terdiversifikasi, atau superantigen yang dapat berinteraksi dengan imunoglobulin permukaan terlepas dari spesifisitas tempat penggabungan. Semua tahap awal perkembangan sel bursal $\mathrm{B}$ didukung oleh konstruksi reseptor yang memungkinkan ekspresi proksimal membran domain sitoplasma Iga dan Igb, termasuk konstruksi sel T messenger (Tm) dan CD8a:Iga. Sebaliknya, tahap selanjutnya dari perkembangan sel B limfosit setelah menetas tidak didukung oleh salah satu dari konstruksi ini (Sayegh dan Ratcliffe, 2000; Aliahmad et al., 2005). Jadi, ekspresi reseptor itu sendiri tampaknya tidak cukup untuk mendukung perkembangan sel bursal B setelah menetas.

Pengamatan bahwa ekspresi Tm tidak mendukung tahap perkembangan selanjutnya membuat tidak mungkin bahwa tahap-tahap ini didorong oleh mitogen yang diturunkan dari usus. Untuk kasus ini, diperlukan konstruksi seperti Tm untuk mendukung semua tahap awal perkembangan sel $B$ yang secara khusus mengecualikan ekspresi reseptor untuk sinyal mitogenik tersebut. Karena ekspresi reseptor yang mengandung domain VH dan VL diperlukan untuk mendukung perkembangan sel B di kemudian hari, sepertinya dapat dikatakan bahwa tahap perkembangan selanjutnya membutuhkan ligasi reseptor sIg yang dimediasi oleh interaksi antara molekul turunan usus dan lengan pengikat antigen dari reseptor sIg. Interaksi seperti itu dapat didasarkan pada interaksi antigen reseptor individu antara repertoar reseptor yang terdiversifikasi dan sejumlah besar epitop antigenik diskrit yang diperoleh dari usus. Dalam keadaan ini, interaksi antibodi antigen individu akan mendorong tahap selanjutnya dari perkembangan sel B dan sel B yang didistribusikan kembali ke korteks folikuler adalah mereka yang telah menemukan antigen serumpun yang masuk dari usus. Sebagai alternatif, seperti yang telah diusulkan dalam model lain dari perkembangan sel B dalam jaringan limfoid terkait usus, superantigen yang berasal dari usus mungkin terlibat dalam ligasi reseptor sIg sel B independen dari spesifisitasnya, tetapi bergantung pada ekspresi reseptor sIg utuh (Silverman, 1992; Pospisil et al., 1995).

Terdapat teori yang mengemuka bahwa tahap selanjutnya dari perkembangan sel $\mathrm{B}$ mungkin bergantung pada interaksi spesifik antara reseptor imunoglobulin permukaan dan antigen serumpun. Orang tidak akan berharap, dan memang ada alasan eksperimental dan teoritis yang kuat untuk tidak mengharapkan, bahwa repertoar sel B perifer akan dibatasi untuk mengenali kekhususan yang ada di bursa dan diperoleh dari usus. Meskipun demikian, karena konversi gen mendiversifikasi repertoar spesifisitas sel B di antara sel bursal yang mengekspresikan imunoglobulin permukaan, ada kemungkinan transmigrasi yang diinduksi antigen ke dalam korteks folikel, dan induksi pembelahan sel yang cepat akan mendorong kelanjutan konversi gen di korteks folikel. Ini mengarah pada prediksi yang dapat diuji bahwa ekspresi AID akan diamati di korteks folikuler. Karena antigen yang berasal dari usus dikeluarkan dari korteks folikel (Sayegh et al., 2000), ini akan menyebabkan sel B spesifik antigen dipilih ke dalam korteks folikel dan menghasilkan beragam spesifisitas dengan tidak adanya antigen. Akibatnya, meskipun mungkin ada tahap spesifik antigen dalam perkembangan sel B, ini tidak serta merta membatasi repertoar sel B. Ada tingkat kematian sel B yang signifikan di bursa, terutama setelah menetas (Motyka dan Reynolds, 1991; Paramithiotis et al., 1995).

Penilaian langsung dari tingkat emigrasi sel bursal ke perifer telah mengungkapkan bahwa tingkat emigrasi sesuai dengan sekitar $1 \%$ dari kumpulan sel $\mathrm{B}$ perifer per jam (Paramithiotis dan Michael, 1994). Demikian pula, berdasarkan penilaian laju pembelahan sel di bursa, laju peningkatan seluleritas bursal dan laju emigrasi sel bursal ke pinggiran, diperkirakan hanya sekitar 5\% sel bursal yang dihasilkan setiap hari beremigrasi ke pinggiran (Lassila, 1989). Sisanya mati in situ dan bursa oleh karena itu merupakan tempat kematian sel B.

Saat ini tidak jelas mengapa begitu banyak sel bursal mati di situ. Di antara sel bursal normal, ada populasi kecil tapi signifikan yang mengekspresikan level imunoglobulin permukaan yang lebih rendah dan siap untuk mengalami apoptosis (Paramithiotis et al., 1995). Akibatnya sel bursal yang kehilangan ekspresi imunoglobulin permukaan mati secara in situ. Jelas sel bursal yang mengalami peristiwa konversi gen yang mengarah ke sekuens $\mathrm{VDJ}_{\mathrm{H}}$ atau $\mathrm{VJ}_{\mathrm{L}}$ yang tidak berfungsi karena, misalnya, untuk generasi gen $\mathrm{V}$ yang mengandung pergeseran bingkai, akan dieliminasi. Namun, analisis frekuensi peristiwa konversi gen nonproduktif tersebut menunjukkan bahwa mereka jarang terjadi, dengan kurang dari 3\% peristiwa konversi gen berada di luar bingkai (Sayegh et al., 1999).

Namun karena ekspresi reseptor sIg tidak hanya membutuhkan ekspresi dari rantai berat dan ringan tetapi juga memasangkan rantai berat dan rantai ringan ke dalam molekul Ig fungsional, kemungkinan alternatifnya adalah bahwa peristiwa konversi gen menghasilkan kombinasi rantai berat dan ringan yang secara intrinsik fungsional tetapi tetap menghasilkan kombinasi rantai berat dan ringan yang tidak dapat berasosiasi satu sama lain untuk membentuk reseptor Ig permukaan. Bukti terbaru menunjukkan bahwa ini mungkin masalahnya. Penilaian kemampuan satu set 24 rantai $m$ dengan panjang penuh 
yang dipilih secara acak dengan jumlah yang setara dari rantai ringan panjang penuh yang dipilih secara acak menunjukkan bahwa hanya sekitar setengah dari kemungkinan kombinasi yang terkait secara efisien. Sisanya terkait secara lemah atau tidak sama sekali, berdasarkan kemampuannya untuk membentuk kompleks reseptor yang diekspresikan di permukaan (Sayegh dan Ratcliffe, 2000). Analisis sekuens dari daerah $\mathrm{VDJ}_{\mathrm{H}}$ dan $\mathrm{VJ}_{\mathrm{L}}$ kombinasi yang melakukan dan tidak berasosiasi dengan tepat tidak mengungkapkan pola urutan yang jelas yang akan memungkinkan prediksi efisiensi asosiasi. Akibatnya, tingkat kematian sel bursal yang signifikan mungkin disebabkan oleh konversi gen kombinasi $\mathrm{VDJ}_{\mathrm{H}} /$ $\mathrm{VJ}_{\mathrm{L}}$ yang gagal untuk berpasangan dengan tepat. Karena semua urutan ini berasal dari sel bursal yang mengekspresikan imunoglobulin permukaan, ketidakmampuan kombinasi reseptor tertentu untuk berasosiasi menjadi reseptor fungsional bukan karena perbedaan intrinsik dalam kualitas rangkaian $\mathrm{VDJ}_{\mathrm{H}}$ dan $\mathrm{VJ}_{\mathrm{L}}$ yang diisolasi karena masing-masing dapat membentuk kompleks reseptor fungsional dengan setidaknya beberapa rantai mitra.

Seluleritas folikel bursal diatur pada tingkat folikel individu. Pada ayam yang diperlakukan sebagai neonatus dengan siklofosfamid dan dibentuk kembali dengan jumlah sel bursal donor yang terbatas, bursa menjadi kolonisasi sebagian. Dalam kondisi ini, beberapa folikel tetap kosong dan yang lainnya dijajah oleh prekursor individu. Seluleritas folikel yang terjajah sama dengan yang terlihat di bursa normal, bahkan jika hanya $10 \%$ dari folikel bursal yang terkolonisasi di resipien yang dibentuk Kembali (Paramithiotis dan Michael, 1994). Oleh karena itu, kemungkinan ada mekanisme selain persyaratan untuk mempertahankan ekspresi sIg yang membatasi ukuran dan seluleritas folikel individu.

Aliran sel dalam folikel bursal yang matang saat ini tidak jelas. Sel medula membelah dengan sangat lambat (Reynolds, 1987) dan saat ini tidak jelas apakah ada aliran sel yang konstan dari medula ke korteks. Demikian pula, meskipun ada pembelahan sel yang cepat di dalam korteks folikuler, tidak jelas apakah ada sel kortikal yang dapat bermigrasi kembali ke medula. Namun, berdasarkan analisis sel di korteks folikel yang telah mengambil bromodeoxyuridine, sel berlabel ditemukan di pinggiran daripada di medula dan dengan demikian jelas tidak ada migrasi utama sel dari korteks ke medula (Paramithiotis dan Michael, 1994).

\section{KESIMPULAN}

Perkembangan garis keturunan sel B ayam menunjukkan beberapa perbedaan mencolok dari model perkembangan sel B hewan pengerat dan primata yang lebih umum dipelajari. Meskipun demikian, beberapa tema umum muncul. Ekspresi imunoglobulin permukaan sel B adalah titik pemeriksaan kritis dalam perkembangan sel B di semua spesies di mana pertanyaan telah dijawab. Demikian pula, meskipun mekanisme molekuler bervariasi di antara spesies, prinsip dasar untuk menghasilkan repertoar primer yang sangat beragam dari spesifisitas sel B secara umum dapat diterapkan. Sementara itu, perkembangan sel $\mathrm{B}$ di usus terkait jaringan limfoid seperti bursa Fabricius, Peyer's patch dan apendiks menunjukkan perbedaan yang mencolok dari jalur yang terlihat dalam perkembangan sel B di sumsum tulang (bone marrow). Karakterisasi basis seluler dan molekuler dari perbedaan-perbedaan ini kemungkinan besar akan memberikan wawasan mendalam tentang evolusi perkembangan garis keturunan sel $\mathrm{B}$.

\section{DAFTAR PUSTAKA}

Ackerman, G.A., and R.A. Knouff. 1959. Lymphocytopoiesis in the bursa of Fabricius. Am. J. Anat. 104:163-205. doi:https://doi.org/10.1002/aja.1001040202.

Aliahmad, P., K.A. Pike, and M.J.H. Ratcliffe. 2005. Cell surface immunoglobulin regulated checkpoints in chicken B cell development. Vet. Immunol. Immunopathol. 108:3-9. doi:https://doi.org/10.1016/j.vetimm.2005.08.009.

Bockman, D.E., and M.D. Cooper. 1973. Pinocytosis by epithelium associated with lymphoid follicles in the bursa of fabricius, appendix, and Peyer's patches. An electron microscopic study. Am. J. Anat. 136:455-477. doi:https://doi.org/10.1002/aja.1001360406.

Dahan, A., C.-A. Reynaud, and J.-C. Weill. 1983. Nucleotide sequence of the constant region of a chicken $\mu$ heavy chain immonoglobulin mRNA. Nucleic Acids Res. 11:53815389. doi:10.1093/nar/11.16.5381.

Dieterlen-Lievre, F. 1987. Hemopoietic Cell Progenitors in the Avian Embryo: Origin and Migrations. Ann. N. Y. Acad. Sci. 511:77-87. doi:https://doi.org/10.1111/j.17496632.1987.tb36239.x.

Le Douarin, N.M., F. Dieterlen-Lièvre, and P.D. Oliver. 1984. Ontogeny of primary lymphoid organs and lymphoid stem cells. Am. J. Anat. 170:261-299. doi:https://doi.org/10.1002/aja.1001700305.

Glick, B., T.S. Chang, and R.G. Jaap. 1956. The Bursa of Fabricius and Antibody Production. Poult. Sci. 35:224225. doi:https://doi.org/10.3382/ps.0350224.

Godin, E., J.A. Garcia-porrerot, A. Coutinho, and F. Dleterlenlievre. 1993. Early Mouse Embryos Contains 364:67-70.

Golovkina, T. V, M. Shlomchik, L. Hannum, and A. Chervonsky. 1999. Organogenic Role of B Lymphocytes in Mucosal Immunity. Science (80-. ). 286:1965 LP 1968. doi:10.1126/science.286.5446.1965.

Grupp, S.A., K. Campbell, R.N. Mitchell, J.C. Cambier, and A.K. Abbas. 1993. Signaling-defective mutants of the B lymphocyte antigen receptor fail to associate with Igalpha and Ig-beta/gamma.. J. Biol. Chem. 268:2577625779 .

Hardy, R.R., Y.-S. Li, D. Allman, M. Asano, M. Gui, and K. Hayakawa. 2000. B-cell commitment, development and selection. Immunol. Rev. 175:23-32. doi:https://doi.org/10.1111/j.1600065X.2000.imr017517.x.

Houssaint, E., A. Toraño, and J. Ivanyi. 1983. Ontogenic restriction of colonization of the bursa of Fabricius. Eur. J. Immunol. 13:590-595. doi:https://doi.org/10.1002/eji.1830130715. 
Humphrey, B.D., C.C. Calvert, and K.C. Klasing. 2004. The ratio of full length $\operatorname{IgY}$ to truncated $\operatorname{IgY}$ in immune complexes affects macrophage phagocytosis and the acute phase response of mallard ducks (Anas platyrhynchos). Dev. Comp. Immunol. 28:665-672. doi:https://doi.org/10.1016/j.dci.2003.11.003.

Lassila, O. 1989. Emigration of B cells from chicken bursa of Fabricius. Eur. J. Immunol. 19:955-958. doi:https://doi.org/10.1002/eji.1830190527.

Leslie, G.A., and L.W. Clem. 1969. PHYLOGENY OF IMMUNOGLOBULIN STRUCTURE AND FUNCTION : III. IMMUNOGLOBULINS OF THE CHICKEN . J. Exp. Med. 130:1337-1352. doi:10.1084/jem.130.6.1337.

Leslie, G.A., and L.N. Martin. 1973. Studies on the Secretory Immunologic System of Fowl. J. Immunol. 110:1 LP - 9.

Li, Y.-S., R. Wasserman, K. Hayakawa, and R.R. Hardy. 1996. Identification of the Earliest B Lineage Stage in Mouse Bone Marrow. Immunity 5:527-535. doi:https://doi.org/10.1016/S1074-7613(00)80268-X.

Magor, K.E., D.A. Higgins, D.L. Middleton, and G.W. Warr. 1994. One gene encodes the heavy chains for three different forms of IgY in the duck.. J. Immunol. 153:5549 LP - 5555.

Mansikka, A. 1992. Chicken IgA H chains. Implications concerning the evolution of $\mathrm{H}$ chain genes.. J. Immunol. 149:855 LP -861 .

Motyka, B., and J.D. Reynolds. 1991. Apoptosis is associated with the extensive B cell death in the sheep ileal Peyer's patch and the chicken bursa of Fabricius: A possible role in B cell selection. Eur. J. Immunol. 21:1951-1958. doi:https://doi.org/10.1002/eji.1830210825.

Paramithiotis, E., K.A. Jacobsen, and M.J. Ratcliffe. 1995. Loss of surface immunoglobulin expression precedes B cell death by apoptosis in the bursa of Fabricius.. J. Exp. Med. 181:105-113. doi:10.1084/jem.181.1.105.

Paramithiotis, E., and J.H.R. Michael. 1994. B cell emigration directly from the cortex of lymphoid follicles in the bursa of Fabricius. Eur. J. Immunol. 24:458-463. doi:https://doi.org/10.1002/eji.1830240229.

Parvari, R., A. Avivi, F. Lentner, E. Ziv, S. Tel-Or, Y. Burstein, and I. Schechter. 1988. Chicken immunoglobulin gammaheavy chains: limited VH gene repertoire, combinatorial diversification by $\mathrm{D}$ gene segments and evolution of the heavy chain locus.. EMBO J. 7:739-744. doi:https://doi.org/10.1002/j.1460-2075.1988.tb02870.x.

Pike, K.A., E. Baig, and M.J.H. Ratcliffe. 2004. The avian Bcell receptor complex: distinct roles of $\operatorname{Ig} \alpha$ and $\operatorname{Ig} \beta$ in Bcell development. Immunol. Rev. 197:10-25. doi:https://doi.org/10.1111/j.0105-2896.2004.0111.x.

Pike, K.A., and M.J.H. Ratcliffe. 2002. Cell surface immunoglobulin receptors in B cell development. Semin. Immunol.

$14: 351-358$ doi:https://doi.org/10.1016/S1044-5323(02)00068-4.

Pospisil, R., G.O. Young-Cooper, and R.G. Mage. 1995. Preferential expansion and survival of B lymphocytes based on VH framework 1 and framework 3 expression: \&quot;positive\&quot; selection in appendix of normal and VH-mutant rabbits. Proc. Natl. Acad. Sci. 92:6961 LP - 6965. doi:10.1073/pnas.92.15.6961.
Ratcliffe, M.J.H. 1996. Chicken immunoglobulin isotypes and allotypes. Weir's Handb. Exp. Immunol. 5th ed., LA Herzenberg, DM Weir, C. Blackwell (eds.). Blackwell Sci. Cambridge, UK 241-247.

Ratcliffe, M.J.H. 2006. Antibodies, immunoglobulin genes and the bursa of Fabricius in chicken B cell development. Dev. Comp. Immunol. 30:101-118. doi:https://doi.org/10.1016/j.dci.2005.06.018.

Reynaud, C.-A., V. Anquez, H. Grimal, and J.-C. Weill. 1987. A hyperconversion mechanism generates the chicken light chain preimmune repertoire. Cell 48:379-388. doi:10.1016/0092-8674(87)90189-9.

Reynaud, C.-A., V. Anquez, and J.-C. Weill. 1991. The chicken $\mathrm{D}$ locus and its contribution to the immunoglobulin heavy chain repertoire. Eur. J. Immunol. 21:2661-2670. doi:https://doi.org/10.1002/eji.1830211104.

Reynaud, C.-A., A. Dahan, V. Anquez, and J.-C. Weill. 1989. Somatic hyperconversion diversifies the single $\mathrm{VH}$ gene of the chicken with a high incidence in the $\mathrm{D}$ region. Cell 59:171-183. doi:https://doi.org/10.1016/00928674(89)90879-9.

Reynaud, C.A., B.A. Imhof, V. Anquez, and J.C. Weill. 1992. Emergence of committed B lymphoid progenitors in the developing chicken embryo.. EMBO J. 11:4349-4358. doi:https://doi.org/10.1002/j.1460-2075.1992.tb05534.x.

Reynolds, J.D. 1987. Mitotic rate maturation in the Peyer's patches of fetal sheep and in the bursa of Fabricius of the chick embryo. Eur. J. Immunol. 17:503-507. doi:https://doi.org/10.1002/eji.1830170411.

Sanchez, M., Z. Misulovin, A.L. Burkhardt, S. Mahajan, T. Costa, R. Franke, J.B. Bolen, and M. Nussenzweig. 1993. Signal transduction by immunoglobulin is mediated through Ig alpha and Ig beta.. J. Exp. Med. 178:10491055. doi:10.1084/jem.178.3.1049.

Sayegh, C.E., S.L. Demaries, K.A. Pike, J.E. Friedman, and M.J.H. Ratcliffe. 2000. The chicken B-cell receptor complex and its role in avian B-cell development. Immunol. Rev. 175:187-200. doi:https://doi.org/10.1111/j.1600065X.2000.imr017507.x.

Sayegh, C.E., G. Drury, and M.J.H. Ratcliffe. 1999. Efficient antibody diversification by gene conversion in vivo in the absence of selection for V(D)J-encoded determinants. EMBO J. 18:6319-6328. doi:https://doi.org/10.1093/emboj/18.22.6319.

Sayegh, C.E., and M.J.H. Ratcliffe. 2000. Perinatal Deletion of B Cells Expressing Surface Ig Molecules That Lack $\mathrm{V}(\mathrm{D}) \mathrm{J}$-Encoded Determinants in the Bursa of Fabricius Is Not Due to Intrafollicular Competition. J. Immunol. 164:5041 LP - 5048. doi:10.4049/jimmunol.164.10.5041.

Schaffner, T., J. Mueller, M.W. Hess, H. Cottier, B. Sordat, and C. Ropke. 1974. The bursa of fabricius: A central organ providing for contact between the lymphoid system and intestinal content. Cell. Immunol. 13:304-312. doi:https://doi.org/10.1016/0008-8749(74)90247-0.

Silverman, G.J. 1992. Human Antibody Responses to Bacterial Antigens: Studies of a Model Conventional Antigen and a Proposed Model B Cell Superantigen. Int. Rev. Immunol. 9:57-78. doi:10.3109/08830189209061783.

Sorvari, T., R. Sorvari, P. Ruotsalainen, A. Toivanen, and P. 
Toivanen. 1975. Uptake of environmental antigens by the bursa of Fabricius. Nature 253:217-219. doi: $10.1038 / 253217 \mathrm{a} 0$.
Taylor, R.L., and F.M. McCorkle. 2009. A landmark contribution to poultry science-Immunological function of the bursa of Fabricius12. Poult. Sci. 88:816-823. doi:https://doi.org/10.3382/ps.2008-00528. 